Zofia Szpringer

\title{
Ocena skutków regulacji poselskiego projektu ustawy o zmianie ustawy o finansach publicznych ${ }^{1}$
}

\author{
Impact assessment of the Deputies' bill amending the Act \\ on Public Finances
}

\begin{abstract}
The aim of the bill - indicated by the applicant - is to prevent bypassing the stabilizing expenditure rule (SER) by shifting various categories of current budget expenditure to public institutions not covered by the SER operation. The result of the bill may be, among others, hindering the payment of additional pensions in the future, but also a stronger guarantee of support for people with disabilities. In addition, the proposed amendment may discourage reducing the value of the Demographic Reserve Fund, which had been planned as a damper for adverse phenomena in the pension system. In the author's opinion, there is a need to review the operation of the SER and to further seal this rule, so that it can affect the sustainability of public finances in the long run.
\end{abstract}

Keywords: public finances, fund, regulatory impact assessment, bill

Celem projektu - wskazywanym przez wnioskodawcę - jest „zapobieżenie omijaniu stabilizującej reguły wydatkowej (SRW) poprzez przesuwanie różnych kategorii bieżących wydatków budżetowych do instytucji publicznych nieobjętych działaniem SRW". Skutkiem realizacji projektu może być m.in. utrudnienie w przyszłości wypłat dodatkowych emerytur, ale także lepsze zabezpieczenie wsparcia dla osób niepełnosprawnych. Ponadto proponowana nowelizacja może zniechęcać do pomniejszania wartości Funduszu Rezerwy Demograficznej, który był planowany jako amortyzator niekorzystnych zjawisk w systemie emerytalnym. W ocenie autorki istnieje potrzeba przeglądu działania SRW i jej dalszego uszczelniania, aby mogła w dłuższym czasie skuteczniej oddziaływać na stabilność finansów publicznych.

Słowa kluczowe: finanse publiczne, fundusz, ocena skutków regulacji, projekt ustawy

doktor nauk ekonomicznych -

naczelnik Wydziału Analiz Społecznych i Ekonomicznych w Biurze Analiz Sejmowych, Kancelaria Sejmu, Biuro Analiz Sejmowych, Wydział Analiz Społecznych i Ekonomicznych, WARSZAWA, POLSKA -

zofia.szpringer@sejm.gov.pl • https://orcid.org/0000-0002-8265-4440

\section{Przedmiot projektu}

Projekt ustawy zmierza do dokonania zmiany $\mathrm{w}$ art. 112aa ustawy $\mathrm{z}$ dnia 27 sierpnia 2009 r. o finansach publicznych (t.j. Dz.U. 2019, poz. 869, ze zm.). Zmiana polega na dodaniu w ust. 3 tego artykułu pkt 5 w brzmieniu: „5) wy-

$1 \quad$ Ocena skutków regulacji poselskiego projektu ustawy o zmianie ustawy o finansach publicznych sporządzona 23 grudnia 2019 r. na zlecenie zastępcy Szefa Kancelarii Sejmu, BAS - WASiE-251/19. 
datków dokonanych w roku n-1 z Solidarnościowego Funduszu Wsparcia Osób Niepełnosprawnych, z wyłączeniem wydatków określonych w art. 6, 6a i 6b ustawy z dnia 23 października 2018 r. o Solidarnościowym Funduszu Wsparcia Osób Niepełnosprawnych (Dz. U. poz. 2192 oraz z 2019 r. poz. 1622 i 1696)”.

Wyjaśniając najprościej powyższą zmianę, można stwierdzić, że wnioskodawcy chodzi o to, aby w nieprzekraczalnym limicie wydatków budżetu państwa ${ }^{2}$, ustalonym zgodnie ze stabilizującą regułą wydatkową (dalej: SRW), nie ujmować wydatków z Solidarnościowego Funduszu Wsparcia Osób Niepełnosprawnych $\mathrm{z}$ roku poprzedniego przewidzianych na inne cele niż związane ze wsparciem osób niepełnosprawnych ${ }^{3}$. Tym samym kwota wydatków przewidziana np. na wypłatę dodatkowego świadczenia pieniężnego dla emerytów i rencistów (tzw. trzynastej emerytury) czy renty socjalnej dokonana w danym roku będzie obniżała limit wydatków na rok następny. Ustawa wchodziłaby w życie 1 stycznia 2020 r.

\section{Podmioty, na które oddziałuje akt}

Akt oddziałuje na:

- osoby, które były i w przyszłości mogłyby być uprawnione do otrzymania jednorazowego świadczenia pieniężnego - tzw. trzynastej emerytury (tj. świadczeniobiorców pobierających emerytury i renty, świadczenia i zasiłki przedemerytalne, renty socjalne oraz rodzicielskie świadczenia uzupełniające); liczba tych osób jest szacowana na ponad 9,8 $\mathrm{mln}^{4}$;

- podmioty wypłacające świadczenia emerytalno-rentowe (Zakład Ubezpieczeń Społecznych, Kasę Rolniczego Ubezpieczenia Społecznego, organy eme-

2 Zgodnie $\mathrm{z}$ art. 110 pkt 2a ustawy o finansach publicznych w budżecie państwa określono kwotę planowanych wydatków, obliczoną zgodnie z art. 112aa ust. 1, oraz kwotę planowanego limitu wydatków, o którym mowa w art. 112aa ust. 3.

3 Na wsparcie osób niepełnosprawnych (art. 6, 6a i 6b) są przeznaczane środki na realizację: 1) programów rządowych i resortowych, mających na celu wsparcie społeczne, zawodowe lub zdrowotne osób niepełnosprawnych oraz realizację zadań związanych z promowaniem i wspieraniem systemu wsparcia osób niepełnosprawnych, a także zadań z zakresu innowacyjnych rozwiązań w zakresie wsparcia osób niepełnosprawnych, w tym obejmujących realizację zadań własnych jednostek samorządu terytorialnego w zakresie wsparcia osób niepełnosprawnych; 2) zadań związanych z promowaniem i wspieraniem systemu wsparcia osób niepełnosprawnych; 3) zadań z zakresu innowacyjnych rozwiązań w zakresie wsparcia osób niepełnosprawnych; a także na wsparcie udzielane w ramach Funduszu Dostępności i na finansowanie świadczenia uzupełniającego, wraz z określonymi w tej ustawie kosztami obsługi wypłaty świadczenia uzupełniającego i kosztami obsługi wniosku.

4 Zob. Ocena skutków regulacji rządowego projektu ustawy o jednorazowym świadczeniu pieniężnym dla emerytów i rencistów w 2019 r. (druk nr 3311 VIII kad.), s. 5. 
rytalne służb mundurowych ${ }^{5}$ ) oraz działające na rzecz niepełnosprawnych (Solidarnościowy Fundusz Wsparcia Osób Niepełnosprawnych, Państwowy Fundusz Rehabilitacji Osób Niepełnosprawnych, jednostki samorządu terytorialnego);

- osoby niepełnosprawne korzystające ze wsparcia Solidarnościowego Funduszu Wsparcia Osób Niepełnosprawnych (ok. 3 mln osób) ${ }^{6}$;

- ministra finansów, upoważnionego m.in. do: wyliczania SRW, dokonywania przeniesień wydatków budżetu państwa oraz wpłat środków z budżetu do Funduszu Rezerwy Demograficznej, wyrażania zgody na udzielanie nieoprocentowanej pożyczki ze środków Funduszu Rezerwy Demograficznej na wniosek określonych dysponentów.

\section{Celowość wprowadzenia aktu}

Wnioskodawca uzasadnia celowość wprowadzenia ustawy potrzebą zapobieżenia „omijaniu stabilizującej reguły wydatkowej (SRW) poprzez przesuwanie różnych kategorii bieżących wydatków budżetowych do instytucji publicznych nieobjętych działaniem SRW". Ma to się przyczynić do wzmocnienia dyscypliny finansów publicznych.

\section{Planowane środki (narzędzia i działania) służące do realizacji celów}

Projekt ustawy - jak można sądzić - powstał w odpowiedzi na uchwaloną 21 listopada 2019 r. ustawę o zmianie ustawy o Solidarnościowym Funduszu Wsparcia Osób Niepełnosprawnych oraz niektórych innych ustaw ${ }^{7}$. Ustawa ta m.in.:

- poszerza zadania Solidarnościowego Funduszu Wsparcia Osób Niepełnosprawnych (dalej: Fundusz) o wsparcie finansowe emerytów i rencistów;

- stanowi, iż środki Funduszu przeznacza się również na finansowanie jednorazowego rocznego świadczenia pieniężnego dla emerytów i rencistów oraz kosztów obsługi wypłaty tego świadczenia, a także renty socjalnej i zasiłku pogrzebowego oraz kosztów ich obsługi;

$5 \quad$ Emerytury służb mundurowych są wypłacane z budżetu państwa (w ramach budżetu MSWiA, MON i MS), funkcjonariusze nie opłacają bowiem składek do ZUS.

6 Zob. Ocena skutków regulacji rządowego projektu ustawy o Solidarnościowym Funduszu Wsparcia Osób Niepełnosprawnych (druk 2848 VIII kad.), s. 3.

7 Zob. prace nad poselskim projektem ustawy o zmianie ustawy o Solidarnościowym Funduszu Wsparcia Osób Niepełnosprawnych oraz niektórych innych ustaw (druk 13 i $13-A)$. 
- poszerza możliwość zaciągania nieoprocentowanych pożyczek, w tym z budżetu państwa, przez dysponenta funduszu, tj. ministra właściwego do spraw zabezpieczenia społecznego, za zgodą ministra właściwego do spraw finansów publicznych na wypłatę jednorazowego rocznego świadczenia pieniężnego dla emerytów i rencistów oraz kosztów obsługi wypłaty tego świadczenia, a także renty socjalnej i zasiłku pogrzebowego oraz kosztów ich obsługi;

- stanowi, iż minister właściwy do spraw zabezpieczenia społecznego przekazuje na wyodrębnione rachunki bankowe Zakładu Ubezpieczeń Społecznych (dalej: ZUS), Kasy Rolniczego Ubezpieczenia Społecznego (dalej: KRUS) i Narodowego Funduszu Zdrowia środki Funduszu na finansowanie wydatków w terminie umożliwiającym wypłatę świadczeń;

- przewiduje, iż w 2019 r. środki na refundację jednorazowego świadczenia pieniężnego dla emerytów i rencistów ${ }^{8}$ wypłacone z Funduszu Ubezpieczeń Społecznych stanowią koszty Funduszu;

- stanowi, że w 2019 r. minister właściwy do spraw finansów publicznych dokonuje wpłaty środków z budżetu państwa do Funduszu Rezerwy Demograficznej, zablokowanych w części 73 - Zakład Ubezpieczeń Społecznych na podstawie art. 177 ust. 1 pkt 3 i ust. 3 pkt 2 ustawy z dnia 27 sierpnia 2009 r. o finansach publicznych;

- przewiduje, że w 2019 r. Funduszowi zostanie udzielona nieoprocentowana pożyczka w kwocie do 9000000 tys. zł ze środków Funduszu Rezerwy Demograficznej zgodnie z art. 59 ust. 1 pkt 4 ustawy z dnia 13 października 1998 r. o systemie ubezpieczeń społecznych ${ }^{9}$;

- zakłada, że w latach 2019-2028 maksymalny limit wydatków będących skutkiem finansowym ustawy wynosi łącznie 32244 tys. zł (tj. będzie o 8550 tys. zł wyższy względem limitu wcześniejszego, ustalonego w kwocie 23694 tys. zł). Planowane przez wnioskodawcę środki (nowelizacja ustawy o finansach publicznych) mogą nie pozwolić na realizację celu wskazanego przez wnioskodawcę projektu. Wynika to przede wszystkim z faktu, iż wnioskodawca odwołuje się do art. 6b ustawy o Solidarnościowym Funduszu Wsparcia Osób Niepełnosprawnych. Przepis ten został zmieniony w uchwalonej ustawie z dnia 21 listopada 2019 r. o zmianie ustawy o Solidarnościowym Funduszu Wsparcia Osób Niepełnosprawnych oraz niektórych innych ustaw. Obecnie daje on możliwość przeznaczenia środków Funduszu nie tylko na świadczenie uzupełniające dla osób niezdolnych do samodzielnej egzystencji, ale także na finansowanie jednorazowego rocznego świadczenia pieniężnego dla emerytów i rencistów oraz kosztów obsługi wypłaty tego świadczenia, a także renty socjalnej i zasiłku pogrzebowego

8 O którym mowa w art. 2 ust. 1 ustawy z dnia 4 kwietnia 2019 r. o jednorazowym świadczeniu pieniężnym dla emerytów i rencistów w 2019 r. (Dz.U. poz. 743).

$9 \quad$ Przy czym zgoda ministra właściwego do spraw finansów publicznych, o której mowa w art. 3 ust. 1a, nie jest wymagana. 
oraz kosztów ich obsługi ${ }^{10}$. Dlatego też dla osiągnięcia celu zakładanego przez wnioskodawcę zasadne byłoby odwołanie się tylko do art. $6 \mathrm{~b}$ ust. 1 pkt 1 (tj. do wydatków, które finansowałyby jedynie świadczenie uzupełniające, „koszty obsługi wypłaty tego świadczenia, koszty obsługi wniosku o świadczenie uzupełniające oraz koszty świadczeń zdrowotnych związanych z wydawaniem orzeczeń dla osób niezdolnych do samodzielnej egzystencji”).

Być może modyfikacji powinny ulec także przepisy uchwalonej ustawy o zmianie ustawy o Solidarnościowym Funduszu Wsparcia Osób Niepełnosprawnych i innych ustaw, np. w odniesieniu do art. 36, określającego maksymalny limit wydatków będących skutkiem finansowym ustawy (ale kwestia ta obecnie znajduje się poza przedłożonym projektem ustawy).

\section{Ocena kosztów i korzyści}

Skutkiem realizacji projektu - w przypadku przyjęcia zmian w odniesieniu do art. $6 \mathrm{~b}$ - może być utrudnienie w przyszłości wypłat dodatkowych emerytur. Wynika to z faktu, iż wypłata takich emerytur mogłaby powodować kilkunastomiliardowe ograniczenie limitu wydatków budżetowych na rok następny.

Umieszczenie w ustawie o finansach publicznych wyłączenia spod reguły wydatkowej środków związanych ze wspieraniem osób niepełnosprawnych mogłoby zaś oznaczać lepsze zabezpieczenie wsparcia udzielanego osobom niepełnosprawnym.

Projekt może także zniechęcać do pomniejszania wartości Funduszu Rezerwy Demograficznej, który był planowany jako amortyzator niekorzystnych zjawisk w systemie emerytalnym. Można zauważyć, iż obecnie wartość tego funduszu nie jest duża (na dzień 31 grudnia 2018 r. wartość jego aktywów finansowych łącznie ze środkami pieniężnymi na rachunku bankowym wyniosła 42,4 mld zł) w porównaniu z kosztami wypłat emerytur i rent (w 2018 r. na wypłaty emerytur i rent z ZUS i KRUS przeznaczono ponad $212 \mathrm{mld} \mathrm{zł})^{11}$.

10 Artykuł 6b ust. 1 stanowi: „Środki Funduszu przeznacza się również na finansowanie: 1) świadczenia uzupełniającego, kosztów obsługi wypłaty świadczenia uzupełniającego, kosztów obsługi wniosku o świadczenie uzupełniające oraz kosztów świadczeń zdrowotnych związanych $\mathrm{z}$ wydawaniem orzeczeń dla osób niezdolnych do samodzielnej egzystencji, o których mowa w art. 11 ust. 1 ustawy z dnia 31 lipca 2019 r. o świadczeniu uzupełniającym dla osób niezdolnych do samodzielnej egzystencji; 2) jednorazowego rocznego świadczenia pieniężnego dla emerytów i rencistów oraz kosztów obsługi wypłaty tego świadczenia, o których mowa w odrębnych przepisach; 3) renty socjalnej, zasiłku pogrzebowego oraz kosztów ich obsługi, o których mowa w art. 14 ust. 1 ustawy z dnia 27 czerwca 2003 r. o rencie socjalnej”. Zmianie ulegają także dalsze ustępy niniejszego artykułu.

11 Zob.: Informacja z wykonania planu budżetu państwa w części 73 - ZUS; Sprawozdanie z wykonania planu finansowego Funduszu Ubezpieczeń Społecznych; Sprawozdanie 
Wydaje się, iż należałoby się zastanowić nad potrzebą przeglądu działania SRW i dalszego uszczelniania tej reguły tak, aby mogła ona w dłuższym czasie skuteczniej oddziaływać na stabilność finansów publicznych.

Obecnie spod SRW wyłączone są m.in. państwowe fundusze celowe, z wyjątkiem funduszy, które dysponują środkami pochodzącymi np. ze składek lub $\mathrm{z}$ dotacji budżetu państwa, a także $\mathrm{z}$ uwagi na ich istotne znaczenie systemowe oraz znaczny i bezpośredni wpływ na wynik sektora general government. Funduszami tymi są fundusze zarządzane przez ZUS, KRUS, Fundusz Pracy, Bankowy Fundusz Gwarancyjny, a także fundusze utworzone, powierzone lub przekazane Bankowi Gospodarstwa Krajowego ${ }^{12}$. Reguła ta wyłącza mniejsze fundusze celowe (np. Solidarnościowy Fundusz Wsparcia Osób Niepełnosprawnych, którego przychody ze składki i daniny solidarnościowej w planie na 2020 r. wyniosły

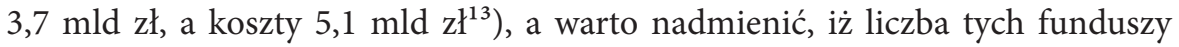
nieustannie rośnie (w projekcie budżetu na 2020 r. jest ich już 35) ${ }^{14}$. To oznacza, iż coraz więcej środków umieszczanych jest poza SRW, co też może być świadectwem obchodzenia tej reguły.

Wydaje się również, że uszczelnienie reguły wydatkowej może w dłuższym czasie pozytywnie oddziaływać na stabilność finansów publicznych, ponieważ pozwoli na działania antycykliczne.

Można też zgodzić się z wnioskodawcą, iż wejście w życie projektowanej ustawy będzie miało pozytywne skutki społeczne w związku ze zwiększeniem przejrzystości życia publicznego. Nie powinno wywoływać negatywnych skutków finansowych dla budżetu państwa oraz budżetów jednostek samorządu terytorialnego.

\section{Podsumowanie - ogólna ocena projektu}

- Projekt ustawy - jak można sądzić - powstał w odpowiedzi na uchwaloną 21 listopada 2019 r. ustawę o zmianie ustawy o Solidarnościowym Funduszu Wsparcia Osób Niepełnosprawnych oraz niektórych innych ustaw.

- Celem projektu wskazywanym przez wnioskodawcę jest „zapobieżenie omijaniu stabilizującej reguły wydatkowej (SRW) poprzez przesuwanie różnych kategorii bieżących wydatków budżetowych do instytucji publicznych nieobjętych działaniem SRW".

z wykonania planu finansowego Funduszu Emerytur Pomostowych; Sprawozdanie z wykonania planu finansowego Funduszu Rezerwy Demograficznej za 2018 rok; Sprawozdanie z wykonania planu rzeczowo-finansowego za 2018 rok, Warszawa, czerwiec 2019.

12 Zob. art. 112aa ust. 1 ustawy o finansach publicznych.

13 Zob. Projekt ustawy budżetowej na rok 2020 (druk sejmowy nr 3829 VIII kad.), s. $13 / 48$.

14 Ibidem, s. 7 i n. 
- W przypadku podpisania przez Prezydenta ustawy z dnia 21 listopada $2019 \mathrm{r}$. celowe byłoby dokonanie zmian w projekcie ustawy dotyczących odwołania nie do całego art. $6 \mathrm{~b}$, ale do jego ust. 1 pkt 1 . W przeciwnym razie cel zakładany przez wnioskodawcę projektu ustawy może nie być osiągnięty.

- Skutkiem projektu (po dokonaniu niezbędnych zmian dotyczących art. 6b) może być m.in. utrudnienie $\mathrm{w}$ przyszłości wypłat dodatkowych emerytur, ale także lepsze zabezpieczenie wsparcia dla osób niepełnosprawnych. Ponadto projekt może zniechęcać do pomniejszania wartości Funduszu Rezerwy Demograficznej, który był planowany jako amortyzator niekorzystnych zjawisk w systemie emerytalnym.

- Wydaje się, iż należałoby się zastanowić nad potrzebą przeglądu działania SRW i dalszego uszczelniania tej reguły tak, aby mogła ona w dłuższym czasie skuteczniej oddziaływać na stabilność finansów publicznych. 